\title{
High Prevalence of Transfusion-Transmitted Virus Infection in Patients with Chronic Liver Diseases in an Endemic Area of Hepatitis B and C Virus
}

\author{
M. Cemil Savas ${ }^{a}$ Cakir Guney ${ }^{b}$ Abdurrahman Kadayıfcı ${ }^{a}$ Ayhan Balkan $^{a}$ \\ Mehmet Koruk $^{a}$ Ayhan Kubar ${ }^{b}$ Ahmet Uygunc
}

Department of a Gastroenterology, Faculty of Medicine, Gaziantep, and Departments of birology and

'Gastroenterology, Gulhane Military Academy of Medicine, Ankara, Turkey

\section{Key Words}

Transfusion-transmitted virus $\cdot$ Prevalence $\cdot$ Chronic liver diseases

\begin{abstract}
Objective: To determine the prevalence and clinical impact of transfusion-transmitted virus (TTV) DNA in patients with chronic liver diseases in the Southeast Anatolia region of Turkey where hepatitis $B$ and $C$ viral infections are endemic. Subjects and Methods: Patients diagnosed with chronic liver disease by clinical, biochemical and histologic means were enrolled in the study. Serum samples of 60 patients (19 males, 41 females) with chronic liver diseases, and of $\mathbf{4 5}$ healthy volunteer blood donors as a control group were collected. The chronic liver disease group consisted of 11 patients with hepatitis $B, 44$ with hepatitis $C$ and 5 with chronic liver disease of unknown etiology. Presence of TTV DNA was investigated by the polymerase chain reaction. Using a scoring system histological grading of inflammation and staging of fibrosis were performed only in the chronic hepatitis $\mathrm{C}$ group. Results: TTV DNA was detected in 47 (78\%) patients with chronic liver disease and 5 (11\%) volunteers in the control group. The difference was statistically
\end{abstract}

\section{KARGER}

Fax +41613061234

E-Mail karger@karger.ch

www. karger.com
(C) 2003 S. Karger AG, Basel

1011-7571/03/0123-0176\$19.50/0

Accessible online at:

www. karger.com/mpp significant $(p<0.001)$. Ten of the $11(91 \%)$ patients with hepatitis B, 32 of 44 (73\%) of those with hepatitis C-related chronic liver disease, and 5 of $5(100 \%)$ of the patients with cryptogenic liver disease were positive for TTV DNA. Conclusion: TTV is highly prevalent in patients with chronic liver diseases in Southeast Anatolia, Turkey but no pathogenic effect attributable to TTV infection was detected.

Copyright $\odot 2003$ S. Karger AG, Base

\section{Introduction}

TT virus is a recently discovered DNA virus that is associated with acute posttransfusion hepatitis of unknown etiology. Initially it was named after the initials (T.T.) of the first patient, but it has been renamed transfusion-transmitted virus (TTV). TTV is a human circovirus with nonenveloped, single-stranded circular DNA, with a particle size of $30-50 \mathrm{~nm}$, comprising a genome of $3.8 \mathrm{~kb}$. An important feature of TTV is an extremely high degree of genomic variability [1-4].

Since the first discovery of TTV in late 1997, a number of investigators have studied the prevalence of TTV DNA in different population groups and geographic areas of the
Dr. M. Cemil Savas

Department of Gastroenterology, Faculty of Medicine, Gaziantep University 27310 Sahinbey, Gaziantep (Turkey)

Tel. +90 532 4930701, Fax +90 342 3601617, E-Mail mcsavas@gantep.edu.tr 
world. In healthy blood donors, the prevalence range of TTV DNA is $1-8 \%$ in the USA, $1.5-27 \%$ in Europe, $11-$ $43 \%$ in Asia, $29-83 \%$ in Africa, and $10-90 \%$ in Japan [5-8]. Although recent studies using a more sensitive, new primer set for the virus have shown a very high prevalence of TTV DNA positivity (up to 93\%) [9-11], its prevalence varies widely according to geographic regions. Hence, we decided to investigate the prevalence of TTV in patients with chronic liver diseases and healthy people in the Southeast Anatolia region of Turkey where viral hepatitis $\mathrm{B}$ and $\mathrm{C}$ are endemic.

\section{Subjects and Methods}

Sixty patients with chronic liver diseases and 45 volunteers were involved in the study. The patients were chosen from the patients who attended the Gastroenterology Clinic of Gaziantep University, Medical Faculty between May and November 2000 and the volunteers were first-time blood donors at the blood bank of the university. The study protocol was approved by the local ethics committee and all the patients gave informed consent. According to clinical, serological and histopathological features, the patients with chronic liver disease consisted of 11 patients with hepatitis $\mathrm{B}$ and 44 patients with hepatitis $\mathrm{C}$ virus $(\mathrm{HCV})$ infection, and 5 patients with hepatitis of unknown etiology (cryptogenic).

The mean age of the chronic hepatitis B group (4 males and 7 females) was $40.3 \pm 16.4$ years. Only 1 patient in this group had transfusion as a risk factor. The diagnosis was based on the presence of elevation of alanine aminotransferase (ALT, $46.4 \pm 26.4 \mathrm{IU} / \mathrm{l}$ ), aspartate aminotransferase (AST, $47.1 \pm 20.6 \mathrm{IU} / \mathrm{l})$, a positive test for HBs antigen for at least 6 months, and histopathologically proven chronic inflammation of the liver.

The mean age of the chronic hepatitis $\mathrm{C}$ group (13 males and 31 females) was $43.8 \pm 14.5$ years. Eight of them had a history of transfusion. Inclusion criteria to this group were elevated ALT (71.6 \pm $48.2 \mathrm{IU} / \mathrm{l})$, AST (70.4 $\pm 56.2 \mathrm{IU} / \mathrm{l})$, a positive test for anti-HCV antibodies and for HCV RNA, and histologically proven chronic inflammation of the liver. Histologic grading of inflammation and staging of fibrosis was performed in the chronic hepatitis $\mathrm{C}$ group by using a modified scoring system [12]. Hepatic inflammation was classified as follows: none $=0 ;$ minimal $=1 ;$ mild $=2 ;$ moderate $=3$, and severe $=4$. Stage of fibrosis was assessed by using a five-grade scale: none $=0 ;$ mild $($ portal expansion $)=1 ;$ moderate $($ portoportal septa $)=$ 2 ; severe (bridging and septal fibrosis) $=3$, and cirrhosis $=4$.

The mean age of the cryptogenic group of 5 patients ( 2 males and 3 females) was $46.4 \pm 15.8$ years; ALT and AST levels were $56.8 \pm$ 32.2 and $62.4 \pm 28.8 \mathrm{IU} / \mathrm{l}$, respectively. All viral, metabolic and autoimmune markers were negative. None of the patients drank alcohol regularly and/or took hepatotoxic drug(s).

The control group consisted of 45 healthy volunteers ( 30 males and 15 females, mean age $41.2 \pm 12.5$ years) with normal liver enzyme levels and negative tests for HBs antigen and anti-HCV. All denied risk practices for parenteral transmission of infectious agents.

Blood was obtained from both the study and control subjects. Each serum sample $(100 \mu \mathrm{l})$ was pretreated with pronase E and its
Table 1. Clinical and hepatic histological characteristics of patients with chronic hepatitis $\mathrm{C}$ according to the presence and absence of TTV infection

\begin{tabular}{lcll}
\hline & $\begin{array}{l}\text { TTV DNA (+) } \\
\text { hepatitis C } \\
\text { patients }\end{array}$ & $\begin{array}{l}\text { TTV DNA (-) } \\
\text { hepatitis C } \\
\text { patients }\end{array}$ & p \\
\hline Patients & 32 & 12 & \\
Sex (M/F) & $6 / 26$ & $5 / 7$ & NS \\
Mean age, years & 53.1 & 54.2 & NS \\
Transfusion history & $5(15 \%)$ & $3(25 \%)$ & NS \\
AST (mean \pm SEM) & $62.4 \pm 41.6$ & $78.3 \pm 57.9$ & NS \\
ALT (mean \pm SEM) & $65.3 \pm 44.3$ & $77.4 \pm 60.4$ & NS \\
\hline Stages of histopathologic findings & & \\
Inflammation & & & NS \\
1 & $5(15.6 \%)$ & $2(16.7 \%)$ & \\
2 & $12(37.5 \%)$ & $5(41.6 \%)$ & \\
3 & $10(31.3 \%)$ & $3(25 \%)$ & \\
4 & $5(15.6 \%)$ & $2(16.7 \%)$ & \\
Fibrosis & & & NS \\
1 & $5(15.6 \%)$ & $1(8.3 \%)$ & \\
2 & $8(25 \%)$ & $4(33.3 \%)$ & \\
3 & $8(25 \%)$ & $5(41.7 \%)$ & \\
4 & $11(34.4 \%)$ & $2(16.7 \%)$ & \\
\hline
\end{tabular}

buffer at $40^{\circ} \mathrm{C}$ and $60 \mathrm{~min}$, and then nucleic acids were extracted with alkali-phenol and chloroform. Extracted nucleic acids were dissolved in $20 \mu \mathrm{l}$ DNAse and RNAse in free deionized distilled water and then subjected to PCR as described previously [9]. Briefly, the thermocycler was programmed first to preheat at $95^{\circ} \mathrm{C}$ for $10 \mathrm{~min}$ to denature samples and then samples $(10 \mu 1$ of extracted DNA was mixed with $2.0 \mathrm{mM} \mathrm{MgCl} 230$ pmol each primer, sense and antisense, $2 \mathrm{U}$ Taq polymerase, $10 \mathrm{~m} M \mathrm{dNTP}$ ) were subjected to 45 cycles consisting of $94^{\circ} \mathrm{C}$ for $20 \mathrm{~s}, 60^{\circ} \mathrm{C}$ for $20 \mathrm{~s}$, and $72^{\circ} \mathrm{C}$ for $30 \mathrm{~s}$ with an MJ Research thermal cycler. Multiple positive and negative controls were run in each PCR assay. PCR products (199 bp in length) were analyzed in a $2 \%$ agarose gel electrophoresis with ethidium bromide staining, and photographed under UV light. The sequences of the TTV-specific primers were T801 $\left(5^{\prime} \mathrm{gct}\right.$ acg tca cta acc acg tg $3^{\prime}$, sense primer, nucleotides 6-25) and T935 (5' ctb cgg tgt gta aac tca cc 3', antisense primer, nucleotides 204-185; b = g, c or t) as designated by Takahashi et al. [9].

Statistical comparison of the groups was made by $\chi^{2}$ test or Fisher's exact test for categorical variables and by the Student's t test or Mann-Whitney U test when appropriate for quantitative values. A p value $<0.05$ was defined as statistically significant.

\section{Results}

TTV DNA was detected in 47 of $60(78 \%)$ patients with hepatitis and 5 of $45(11 \%)$ healthy blood donors. The difference between the groups was statistically signifi- 
cant $(\mathrm{p}<0.001)$. The frequency rates of TTV were also significantly high in patients with hepatitis of unknown origin (5 of 5, 100\%), hepatitis B infection (10 of 11 patients, $91 \%$ ) and hepatitis C infection (32 of 44, 73\%) as compared to the control group $(11 \%, \mathrm{p}<0.001$ in all subgroups).

Since the number of patients with hepatitis B or hepatitis of unknown origin was limited, comparison between TTV (+) and TTV (-) was done only for hepatitis C. TTVinfected and noninfected patients with chronic hepatitis $\mathrm{C}$ are given in table 1 . The results did not reveal any significant differences concerning clinical and laboratory features. No impact of TTV infection was seen on liver histopathologic findings such as grade of inflammation $(p=0.98)$ or stage of fibrosis $(p=0.51)$ in the patients with chronic hepatitis $\mathrm{C}$.

\section{Discussion}

Based on the high prevalence of TTV infection in Japanese patients [2] it was initially suggested that TTV could be associated with posttransfusion hepatitis of unknown etiology and other cryptogenic liver diseases. However, high prevalence of the virus in the healthy population [58] and the lack of a clear association of TTV infection with a particular group of liver disease in subsequent studies strongly suggested that TTV does not cause hepatic inflammation [13-15]. In this study, we used the new primer set defined by Takahashi et al. [9] and found that only $11 \%$ of healthy subjects were TTV-positive, thereby indicating that TTV is not prevalent in the general population of Southeast Anatolia, Turkey.

The role of TTV in chronic hepatitis of unknown etiology has been studied extensively in recent years [2, 1620]. The prevalence of TTV DNA in patients with cryptogenic chronic liver disease did not differ from that of the general population in Japan [16], Spain [17], Thailand [18] and the USA $[19,20]$. The findings of these studies would indicate a lack of association between TTV DNA infection in patients with liver disease of unknown etiology and healthy blood donors.

A high prevalence of TTV (78\%) was found in patients with chronic hepatitis $\mathrm{B}$ and $\mathrm{C}$ infections. However other studies reported lower rates of $20-37 \%$ and $5-27 \%$ for hepatitis $\mathrm{B}$ and $\mathrm{C}$ infections, respectively $[13,17,18,21$, 22 ]. The high prevalence of hepatitis $B(91 \%)$ and $C(73 \%)$ in our region could have contributed to the high prevalence of TTV probably through common transmission routes. Hepatitis $\mathrm{B}$ and $\mathrm{C}$ infections are very common within same family members, and therefore mother-toinfant transmission could be a risk factor in our region. An other important route of transmission could be the use of the same needles in infants during previous vaccination programs.

No difference between TTV-positive and -negative chronic hepatitis $\mathrm{C}$ patients was noticed in this study. Liver histologic findings such as stage of inflammation and grade of fibrosis did not differ in patients with TTV-positive or -negative chronic hepatitis $\mathrm{C}$ infection, thereby indicating minimal or no impact of TTV on hepatic pathology in this study (table 1), a finding consistent with previous reports [22-24]. Due to its wide distribution of TTV and its weak association with disease state, it has been suggested that TTV may represent a part of the human microflora [25].

It is important to point out that in this study in evaluation the prevalence of TTV, we detected only persons with viremia; there could have been patients with active liver infections that were negative on plasma PCR or patients with past exposure as evidenced by serological assays. Newly defined IgM class antibodies may be important in further evaluation of this group of patients [26].

\section{Conclusion}

The prevalence of TTV in Southeast Anatolia, Turkey is very high in patients with chronic liver disease, but association with disease state is not clear. Further studies especially with new serologic assays to diagnose acute and past infection are needed.

\footnotetext{
$178 \quad$ Med Princ Pract 2003;12:176-179
} 


\section{References}

1 Nishizawa T, Okamoto H, Konishi K, Yoshizawa H, Miyakawa Y, Mayumi M: A novel DNA virus (TTV) associated with elevated transaminase levels in posttransfusion hepatitis of unknown etiology. Biochem Biophys Res Commun 1997;241:92-97.

2 Okamoto H, Nishizawa T, Kato N, Ukita M, Ikeda $\mathrm{H}$, Iizuka $\mathrm{H}$, Miyakawa $\mathrm{M}$, Mayumi $\mathrm{M}$ : Molecular cloning and characterization of a novel DNA virus (TTV) associated with posttransfusion hepatitis of unknown etiology. Hepatol Res 1998;10:1-16.

3 Miyata H, Tsunoda H, Kazi A, Yamada A, Khan MA, Murakami J, Kamahora T, Shiraki $\mathrm{K}$, Hino S: Identification of a novel GC-rich 113-nucleotide region to complete the circular, single-stranded DNA genome of TT virus, the first human circovirus. J Virol 1999;73:35823586.

4 Mushahwar IK, Erker JC, Muerhoff AS, Leary TP, Simons JN, Birkenmeyer LG: Molecular and biophysical characterization of TT virus: Evidence for a new virus family infecting humans. Proc Natl Acad Sci USA 1999;96:31773182 .

5 Allain JP: Emerging viral infections relevant to transfusion medicine. Blood Rev 2000;14:173181.

6 Simmonds P, Davidson F, Lycett C, Prescott LE, MacDonald DM, Ellender J, Yap PL, Ludlam CA, Haydon GH, Gillon J, Jarvis LM: Detection of a novel DNA virus (TTV) in blood donors and blood products. Lancet 1998; 352:191-195.

7 Prescott LE, Simmonds P: Global distribution of transfusion-transmitted virus. N Engl J Med 1998;339:776-777.

8 Abe K, Inami T, Asano K, Miyoshi C, Masaki N, Hayashi S, Ishikawa K, Takebe Y, Win KM, El-Zayadi AR, Han KH, Zhang DY: TT virus infection is widespread in the general populations from different geographic regions. J Clin Microbiol 1999;37:2703-2705.
9 Takahashi K, Hoshino H, Ohta Y, Yoshida N, Mishiro S: Very high prevalence of TT virus (TTV) infection in general population of Japan revealed by a new set of PCR primers. Hepatol Res 1998;12:233-239.

10 Biagini P, Gallian P, Tounissi M, Cantaloube JF, Zapitelli J, De Lamball X, De Micco P: High prevalence of TT virus infection in French blood donors revealed by the use of three PCR systems. Transfusion 2000;40:590595.

11 Okamoto H, Takahashi M, Nishizawa T, Ukita M, Fukuda M, Tsuda T, Miyakawa Y, Mayumi M: Marked genomic heterogeneity and frequent mixed infection of TT virus demonstrated by PCR with primers from coding and non-coding region. Virology 1999;259:428436.

12 Desmet VJ, Gerber M, Hoofnagle JH, Manns M, Scheuer PJ: Classification of chronic hepatitis: Diagnosis, grading and staging. Hepatology 1994;19:1513-1520.

13 Naoumov NV, Petrova EP, Thomas MG, Williams R: Presence of a newly described human DNA virus (TTV) in patients with liver disease. Lancet 1998;352:195-197.

14 Kanda T, Yokosuka O, Ikeuchi T, Seta T, Kawai S, Imazeki F, Saisho H: The role of TT virus infection in acute viral hepatitis. Hepatology 1999;29:1905-1908.

15 Kato T, Mizokami M, Orito E, Nakano T, Tanaka Y, Ueda R, Hirashima N, Iijima Y, Kato T, Sugauchi F, Mukaide M, Shimamatsu K, Kage M, Kojiro M: High prevalence of TT virus infection in Japanese patients with liver diseases and in blood donors. J Hepatol 1999; 31:221-227

16 Chayama K: Detection of TT virus DNA in patients with non-A to $\mathrm{G}$ liver diseases. Nippon Rinsho 1999;57:1295-1299.

17 Gimenez-Barcons M, Forns X, Ampurdanes S, Guilera M, Doler M, Soguero C, SanchezFueyo A, Mas A, Bruix J, Sanchez-Tapias JM, Rodes J, Saiz JC: Infection with a novel human DNA virus (TTV) has no pathogenic significance in patients with liver diseases. $\mathrm{J}$ Hepatol 1999;30:1028-1034.
18 Tangkijvanich $\mathrm{P}$, Theamboonlers A, Hirsch $\mathrm{P}$, Kullavanijaya P, Suwangool P, Poovorawan Y: TT virus infection in chronic liver disease. Hepatogastroenterology 1999;46:1053-1058.

19 Matsumoto A, Yeo AE, Shih JW, Tanaka E, Kiyosawa K, Alter HJ: Transfusion-associated TT virus infection and its relationship to liver disease. Hepatology 1999;30:283-288.

20 Kadayıfcı A, Gueney C, Uygun A, Kubar A, Bagci S, Dagalp K: Similar frequency of TT virus infection in patients with liver enzyme elevations and healthy subjects. Int J Clin Pract 2001;55:434-436.

21 Asabe N, Okamura H, Tokuue H, Takasu M, Takahashi S, Saito S: A comparative study of TTV co-infection in patients with chronic liver disease B, C, and non-B-non-C. Nippon Rinsho 1999;57:1362-1365.

22 Tuveri R, Jaffredo F, Lunel F, Nalpa B, Pol S, Feray C, Marcellin P, Thibault V, Delagneau JF, Opolon P, Scarpa B, Brechot C, Thiers V: Impact of TT virus infection in acute and chronic, viral- and non viral-related liver diseases. J Hepatol 2000;33:121-127.

23 Meng XW, Komatsu M, Goto T, Nakane K, Ohshima S, Yoneyama K, Lin JG, Watanabe S: Clinical significance of TT virus in chronic hepatitis C. J Gastroenterol Hepatol 2001;16: 202-208.

24 Watanabe H, Saito T, Kawamata O, Shao L, Aoki M, Terui Y, Mitsuhashi H, Matsuo T, Takeda Y, Saito K, Togashi H, Shinzawa H, Takahashi T: Clinical implications of TT virus superinfection in patients with chronic hepatitis C. Am J Gastroenterol 2000;95:1776-1780.

25 Saback FL, Palmer TE, Sabino RR, Carvalho SM, Amorim LM, Gaspar AM, Oliveira ML, Yoshida CF, Niel C: Infection with hepatitis A and TT viruses and socioeconomic status in Rio de Janeiro, Brazil. Scand J Infect Dis 2001; 33:121-125.

26 Tsuda F, Takahashi M, Nishizawa T, Akahane Y, Konishi K, Yoshizawa H, Okamoto H: IgMclass antibodies to TT virus (TTV) in patients with acute TTV infection. Hepatol Res 2001; 19:1-11. 